\title{
Sustainability Assessment of Large Irrigation Dams in Senegal: A Cost-Benefit Analysis for the Senegal River Valley
}

\author{
Stanislaw Manikowski ${ }^{1,2}$ and Alexandre Strapasson ${ }^{3 *}$ \\ ${ }^{1}$ Centre for Development, Environment and Policy, School of Oriental and African Studies, University of London, London, UK, \\ ${ }^{2}$ Centre Agro-Eco, Montreal, QC, Canada, ${ }^{3}$ Centre for Environmental Policy, Imperial College London, London, UK
}

OPEN ACCESS

Edited by:

Luuk Fleskens,

University of Leeds, UK

Reviewed by:

Indira Devi Puthussery,

Kerala Agricultural University, India

Mongi Sghaier,

Institute of Arid land, Tunisia

*Correspondence:

Alexandre Strapasson alexandre.strapasson@imperial.ac.uk

Specialty section:

This article was submitted to Agroecology and Land Use Systems,

a section of the journal

Frontiers in Environmental Science

Received: 16 January 2016 Accepted: 02 March 2016

Published: 17 March 2016

Citation:

Manikowski S and Strapasson A (2016) Sustainability Assessment of Large Irrigation Dams in Senegal: A Cost-Benefit Analysis for the Senegal River Valley. Front. Environ. Sci. 4:18.

doi: 10.3389/fenvs.2016.00018
Starting in the 1970s, the Senegalese Government invested in the development of irrigated schemes in the Senegalese part of the Senegal River Valley (S-SRV). From that time to 2012, the irrigated schemes increased from 10,000 to more than 110,000 ha. In the meantime, the economic viability of these schemes started to be questioned. It also appeared that the environmental health and social costs might outweigh the benefits of irrigation. Using a life cycle assessment (LCA) approach and project cost-benefits modeling, this study (i) quantified the costs and benefits of the S-SRV irrigated rice production, (ii) evaluated the costs and benefits of its externalities, and (iii) discussed the irrigated rice support policy. The net financial revenues from the irrigated schemes were positive, but not their economic equivalences. The economic return rate (EER) was below the expected $12 \%$ and the net present value (NPV) over 20 years of the project represented a loss of about US\$-19.6 million. However, if we also include the project's negative externalities, such as the reduced productivity of the valley ecosystems, protection cost of human health, environmental degradation, and social impacts, then the NPV would be much worse, approximately US\$-572.1 million. Therefore, the results show that to stop the economic loss and alleviate the human suffering, the S-SRV development policy should be revised using an integrated approach and the exploitation technology should aim at environmental sustainability. This paper may offer useful insights for reviewing the current Senegalese policies for the valley, as well as for assessing other similar cases or future projects worldwide, particularly in critical zones of developing countries.

Keywords: ecological economics, lifecycle assessment, land use change, donor responsibility, policy implications

\section{INTRODUCTION}

The construction of large-scale dams for irrigation is in the political agenda of several developing countries, aiming at increasing their local food production and promoting food security. Several multilateral funding donors and governments have supported investments in new irrigation projects worldwide. However, these projects rarely present a comprehensive sustainability assessment, including not only economic variables, but also potential environmental and social impacts and mitigation measures. To show the importance of this issue and lessons to be learnt for future projects alike, this article presents a critical case study of a large-scale dam 
system constructed for the production of irrigated rice, among other uses, in the Senegal part of the Senegal River Valley (S-SRV).

By the mid of the last century, the Senegalese population started to develop diet preference for rice as basic ingredient of the everyday meal. Its consumption started to increase from 163 thousand tons in 1960 to 1.5 million tons of rice in 2015 (IRRI - International Rice Research Institute, 2015, citing USDA data). In the same period, the total population grew from approximately 3.2 million to 15 million inhabitants (World Bank, 2015) and, consequently, the per capita consumption of rice increased from $51 \mathrm{~kg}$ per person a year to $100 \mathrm{~kg}$ per person a year, respectively. During this rapid consumption growth, the Senegalese Government started to promote the local rice production and develop the irrigated rice production schemes (Dieng and Gueye, 2005; Ministère de l'Agriculture, 2009) in order to improve local welfare and to reduce rice imports and foreign currency expenses. To this purpose (among others), Senegal, jointly with Guinea, Mali and Mauritania launched a program for the construction of dams in the Senegal River, crossing the four countries.

The dams were constructed by 1988 and the irrigated agriculture (mostly devoted to rice) in the S-SRV started to develop. However, soon after the dams' construction it appeared that the benefits from the irrigated rice were not as initially expected (PNUE, 2005). It became evident that the environmental, health and social impacts caused by the modifications in the river flow introduced by the dams' construction and the creation of the irrigated schemes were significantly higher than previously estimated (FAO, 2003). Sow et al. (2002), for example, started to question if the gains from the increased irrigation potential in the S-SRV would be sufficient to justify the human costs involved in the projects. In spite of these warnings, the Senegalese government has continued promoting the S-SRV irrigated rice extension policy (Ministère de l'Agriculture, 2009, 2010) and recently through the Accelerated Program for Agriculture in Senegal (PRACAS, 2015a,b,c).

This paper aims at clarifying the controversies around the irrigated rice production viability and the cost of its externalities. It presents an original assessment, giving new insights to further policies, and lessons to similar initiatives in other countries. It builds on a thesis about the same topic recently defended by the lead author (Manikowski, 2015) at SOAS, University of London. The paper provides a comprehensive and quantified analysis that goes beyond the available studies here discussed, in terms of methodology and accuracy. Further details about the presented calculations can be found in the thesis, which serves as a supplementary document to this article.

\section{Objectives}

The main objectives are to:

- quantify the costs and benefits of the S-SRV irrigated rice production;

- evaluate the costs and benefits of its externalities; and

- clarify the soundness of the S-SRV irrigated rice support policy.

\section{Research Problem}

The key questions that the paper aims to answer are following described:

- What are the financial and economic costs and benefits of the irrigated agriculture in the S-SRV?

- What are the environmental and social costs of the irrigated agriculture in the S-SRV?

- Is the political and financial support to the irrigated agriculture development in the S-SRV justifiable?

\section{HISTORICAL BACKGROUND}

By 1988, the construction of two dams (the Diama and Manantali dams) and the major infrastructure were completed at the total cost of about US\$830 million (Gould and Zobrist, 1989) mostly financed by 13 bilateral donors and international institutions (Ndao, 1999). The Diama dam is situated on the SenegalMauritania border $27 \mathrm{~km}$ from the river estuary, and was designed to stop the salt water intrusion to the river during the dry season. The Manantali dam was constructed in Mali, about 1200 kilometers south-west of the river mouth, aimed to store the water from the Guinean confluents and ensure that the river maintains the desired level of water throughout the year (DeGeorges and Reilly, 2006). In addition to providing water for irrigation, the project generated $740 \mathrm{GWh}^{-1} \mathrm{y}^{-1}$ of electricity (KfW BEI AFD, 2009), and was designed to ensure the future navigability of the lower portion of the river and facilitate the development of the mining industry (OMVS, 2012).

Thanks to the project, Senegal increased its potential for irrigated agriculture in the S-SRV from about 10,000 (Ministère de l'Agriculture, 1985) to 240,000 ha and received $33 \%$ of the generated electric power which allowed to cover $30 \%$ of the electricity demand from Dakar (OMVS, 2012; FAO, 2015). To manage the regional Senegal River investments and the associated water reserves, in 1972, the riparian countries created a Senegal River Basin Organization or Organisation pour la Mise en Valeur du Fleuve Sénégal-OMVS (2008).

\section{Irrigated Rice Promotion Policy}

In Senegal, the irrigated rice growing started to be politically supported in 1977 through the adaptation of an Agricultural Program or Programme Agricole, which was followed in the years 1985-1994 by a New Agricultural Policy or Nouvelle Politique Agricole (Dieng and Gueye, 2005). After 2000, the political support for the rice growing intensification increased through a Great Rural Development and Food Abundance Offensive or Grande Offensive Agricole pour la Nourriture et l'Abondance (GOANA) and its Rice Self-Sufficiency Program Programme National d'Autosuffisance en Riz (PNAR) (Ministère de l'Agriculture, 2009, 2010). The objective of these programs was to achieve the rice self-sufficiency by 2012 (FAO, 2010). Since the objective was not achieved, the actual rural development policy "Program PRACAS" is targeting the year 2017 for the selfsufficiency achievement (PRACAS, 2015a,b,c). The evolution of rice production and rice imports in Senegal and the growing gap between production and imports are illustrated in Figure 1. 


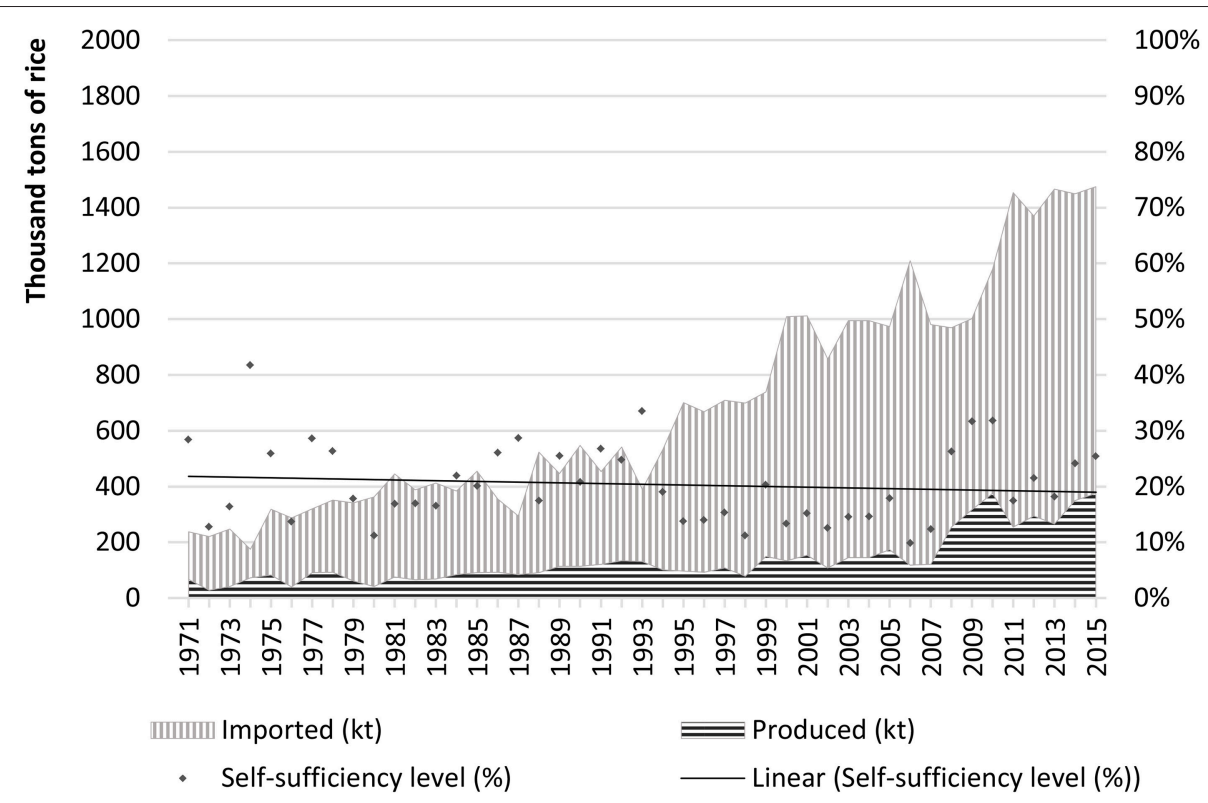

FIGURE 1 | Growth of rice production in Senegal and rice imports from abroad between 1970 and 2015. Data source: |RR| - |nternational Rice Research Institute (2015), using USDA database.

\section{Expected Benefits and Impacts of the S-SRV Dams}

The Senegalese Government's evaluations of the S-SRV irrigated rice production emphasized the high financial returns to the growers and the economic benefits to the country from the rice import reduction (GOANA, 2008; Ministère de l'Agriculture, 2009; SAED, 2009a). However, after a thorough analysis, the soundness of the decision to invest in irrigated rice schemes became less obvious (PNUE, 2005). KfW BEI AFD (2009) in an evaluation of the Senegal River dams' project concluded that the revenues from rice exploitation schemes in Senegal were so low that they could not even cover the maintenance costs of the infrastructures, although without providing detailed figures. Before the start of the project, the studies about the environmental and social externalities indicated that the dams' construction would have minor or positive impacts (Gannett et al., 1978). However, in reality, as early as 2 years after the dam's opening, severe and unpredicted health impacts and environmental consequences started to appear, because of the whole-year presence of stagnant water and abundant aquatic vegetation, among other issues (Diop and Jobin, 1994).

In spite of the importance of the negative externalities, both the Government of Senegal and the OMVS have taken limited actions to mitigate the disturbances and protect the S-SRV human population and environment. The general health problems of the Senegalese population were the subject of two nation-wide governmental programs: The Poverty Reduction Strategies (Republic of Senegal, 2006, 2012a), and a Multi-Year Health Prevention Plan (Republic of Senegal, 2012b). Nevertheless, in both programs, the specific health problems of the S-SRV were not included. OMVS prepared several environment management documents and planned some actions, but they were not yet fully implemented (OMVS, 2008, 2013b; OMVS, c., 2015).

\section{METHODS}

The sustainability assessment here presented is based on a costbenefit model for the evaluation of the S-SRV irrigation schemes and the quantification of its externalities. It is organized like a life cycle assessment (LCA) approach (SAIC, 2006; UNEP, 2009), covering the main stages of the assessed case, including cash flow analysis, net present values (NPV) and economic rate of return (EER). It develops and systematizes an evaluation of internal and external consequences of implementation of the decision to invest in the irrigated agriculture in S-SRV in association with the construction of dams in the Senegal River. The financial benefits from irrigated schemes to individual farmers were expressed in terms of net revenue. The economic benefits and the cost or benefits of the project externalities were expressed by NPVs and ERR. The coefficients were calculated following the standard models of the project's cost flow that includes the initial investment (year zero) and the succession of costs and benefits from the year one to the end of the project (Gittinger, 1966; EDRC, 1997; Belli et al., 2001).

\section{General Assumptions}

The initial investment for building the irrigated schemes includes the construction of all irrigation canals, installation of the water pumping system and preparation of parcels. The dams' construction cost was not included, because the dams were built for multiple purposes, and the distribution of this cost among the usage in the four countries is not available to date.

The model was based on the following general assumptions: 
(i) The initial investment for the construction of irrigated schemes (year zero) corresponds to the year 2009; the first year of the exploitation corresponds to the year 2010. The selection of 2009 as a first year of the model was justified since:

a. the 2009 was the first year of the GOANA and PNAR programs;

b. in 2009 the parastatal Society of Development of Senegal Valley (SAED) published a standard production model for the S-SRV main irrigated crops.

(ii) After the initial investment, an irrigated scheme can be exploited during 20 years (GOANA, 2008). Its "scrap" value estimated at $20 \%$ of the initial investment was added to the benefits in the 20th year of the project.

(iii) The NPV and ERR represent a not adjusted for inflation flow of net benefits.

(iv) The discount rate for the NPVs of the rural production was equal to $12 \%$. This assumption follows the example of the World Bank's cost-benefit evaluations of the rural development projects including the S-SRV development support projects (World Bank, 2006, 2013). Following the World Health Organization's (WHO) guidance (Goodman et al., 1999; WHO, c., 2014), the discounted rate for the NPVs of the health project's cost-benefits was assumed at $3 \%$. The use of two different discount rates reflects the perception that the project investment value declines more rapidly over time than the value associated with human health impacts (see Pearce et al., 2006; WHO, 2008).

(v) The incremental benefit from the irrigated scheme was equal to the flow of benefits minus the production value of S-SRV humid zones estimated by IUCN at US $\$ 17.8$ per hectare per year (Ly and Zein, 2009).

Moreover, to calculate the economic costs and benefits, the financial data were converted into their economic values. The methods of conversion were based on Potts (2002). The cultivation budget for the irrigated rice, corn, and onion in the SSRV was based on the standard recommended budgets for these cultures by $\operatorname{SAED}(2009 \mathrm{a}, \mathrm{b}, \mathrm{c})$ with the following modifications:

- the values of the subsidies for the pesticides and fertilizers (GOANA, 2008) were removed from the farmer's financial costs;

- the cost of family labor [US\$2.02 per day, equivalent to the daily hired labor cost, according to $\operatorname{SAED~(2009a,b,c)]~was~}$ included in the budget.

The budget for tomato growing was that specified by the Senegalese Agricultural Ministry (Ministère de l'Agriculture et de l'Hydraulique, 2005). The costs of sweet potatoes production were recalculated from Tewe et al. (1995) ${ }^{1}$. The farm gate prices for crops in Senegal were from FAOSTAT (2015).

In conformity with the SAED (2009a,b,c), the initial investment in the construction of irrigation schemes was not included in the evaluation of benefits to farmers (financial

\footnotetext{
${ }^{1}$ The budget for growing the sweet potato in the irrigation fields in Senegal was not available.
}

benefits). However, this investment, assumed equal to US $\$ 6353.2$ per hectare (Ministère de l'Agriculture, 2009), was included in the evaluation of the economic cost-benefits.

\section{Data Sources}

The data used in the model were retrieved from documents published by the Senegalese government, parastatal organizations, private sector, and from research articles. Whenever available, the data provided by the government or parastatal organizations (considered as "official" data) were used as a baseline for the study. Data from other independent sources were used to validate the model and evaluate its sensitivity.

To ensure the comparability of costs from different years and sometimes expressed in different currency units, the costs were adjusted for inflation and converted to US dollars. The costs of initial investments were converted to their 2009 US dollars value (a zero year of the model), the costs of production inputs and benefits to their 2010 US dollars values (the first year of the model). The inflation coefficients and the exchange rates were based on the World Development Indicators (World Bank, 2015).

\section{RESULTS}

The sustainability assessment and modeling results are detailed in five sections: (1) productivity of the S-SRV irrigated schemes, (2) other S-SRV productions related to the irrigated schemes, (3) impacts of the irrigated schemes on human health, (4) impacts on environment, and (5) social impacts. The valuation of benefits and costs was carried out using studies conducted by various authors, not necessarily from the same locality, but the necessary adjustments, references, and clarifications are noted.

\section{Productivity of the S-SRV Irrigated Schemes}

The S-SRV has two rice cropping seasons: warm dry season (from March to June) and wet season (from June to November); the valley has also a cold dry season (from November to March) used for gardening and growing corn, onion, tomato, and sweet potato (Buisse et al., 2011). Since the S-SRV climate allows two rice-growing seasons per year (Fraval et al., 2002), the optimally planned, $100 \%$ cropping intensity (CI) is equal to two harvests from one unit of irrigated scheme per year, but such a high CI was never achieved (KfW BEI AFD, 2009; OMVS, 2011). In particular, in 2010 the CI was equal to $42.2 \%$ (Khouma, 2011, recalculated; CGERV, 2012).

\section{Financial Benefits}

Following the SAED convention, the financial costs and benefits were calculated for one hectare-season and not for the hectare during the whole year. According to this scenario, the revenues from all crops cultivated in the irrigated schemes were financially beneficial to growers (Table 1), but the benefits from rice and corn were three to nine times lower than those from onion, tomatoes or sweet potatoes, at least for the assessed period. Overall, the rice that was growing over $89 \%$ of hectares-seasons contributed to $61 \%$ of the total irrigated production value of 
TABLE 1 | Revenues to growers from hectare in the irrigated scheme of the S-SRV corresponding to 2010.

\begin{tabular}{|c|c|c|c|c|c|c|}
\hline $\begin{array}{l}\text { Crop } \\
\text { Season }\end{array}$ & \multicolumn{2}{|c|}{ Rice* $^{*}$} & $\begin{array}{c}\text { Corn }{ }^{\star *} \\
\text { Dry }\end{array}$ & $\begin{array}{c}\text { Onion }^{\star \star} \\
\text { Dry }\end{array}$ & $\begin{array}{c}\text { Tomato** } \\
\text { Dry }\end{array}$ & $\begin{array}{c}\text { Sweet potato }{ }^{\star *} \\
\text { Dry }\end{array}$ \\
\hline Yield (tons per hectare-season) & 6.0 & 6.0 & 3.5 & 25.31 & 28.03 & 23 \\
\hline Farm gate price (US\$ per ton) $)^{\star \star \star}$ & 266.6 & 266.6 & 256.3 & 164.0 & 222.1 & 377.3 \\
\hline Input costs (US\$ per hectare-season) & 864.7 & 813.9 & 793.6 & 1563.6 & 807.6 & 1583.0 \\
\hline Net revenue to producer (in US\$ from one hectare-season) & 734.5 & 785.5 & 103.5 & 2588.4 & 5417.8 & 7095.0 \\
\hline
\end{tabular}

*Surface and yield based on CGERV (2012).

**Surface and yield based on Khouma (2011).

${ }^{* \star *}$ Farm gate price (FAOSTAT, 2015).

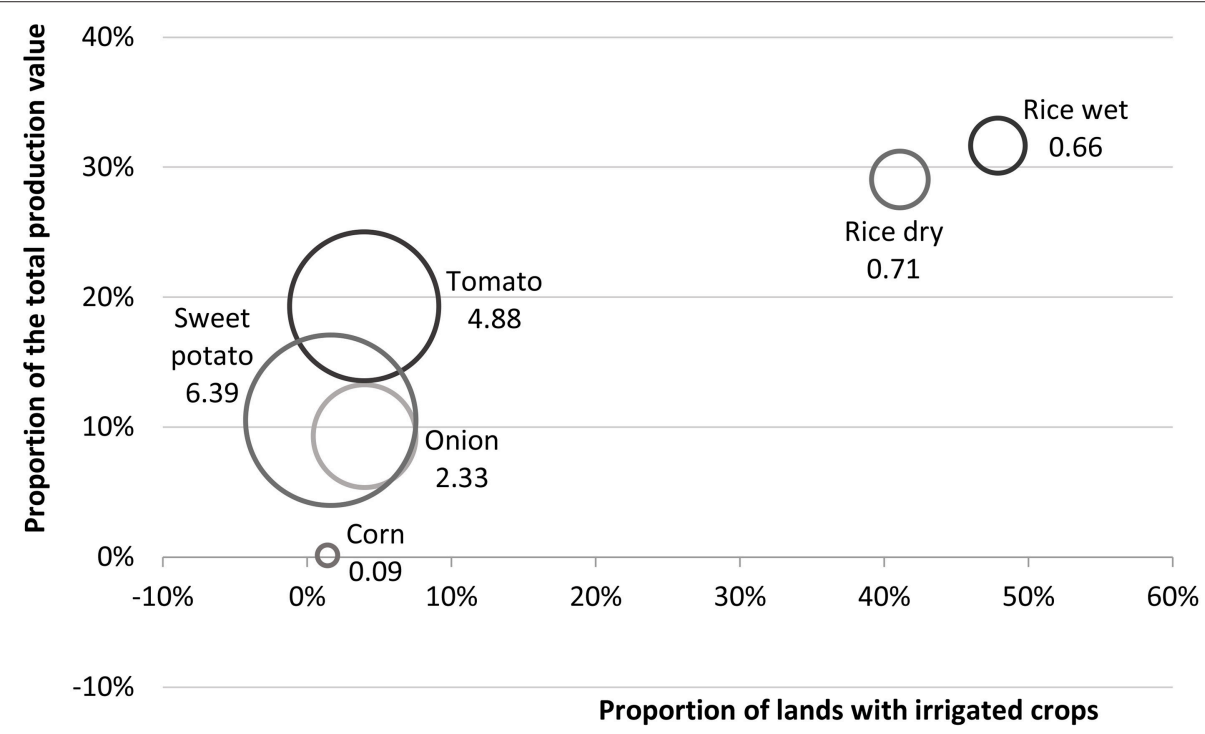

FIGURE 2 | Production value per land use in the total share of irrigated crops in the S-SRV. The circles' values represent the power of each crop to add production value proportionally to their respective areas in the total irrigated land surface, i.e., the coefficient of proportion (Y/X).

the S-SRV, whereas the three non-cereal crops growing on $10 \%$ contributed to $39 \%$ to the global production (Figure 2).

\section{Economic Benefits}

To calculate the economic benefits, the financial data was converted into economic values and the cost of construction of the irrigated schemes was included. The economic cost-benefits were evaluated according to two scenarios:

- Scenario I considered the case where the CI was equal to $100 \%$. Under this scenario only corn is cultivated at an economic loss: the NPV over 20 years equal to US\$-5302 and the ERR-6.4\%. The return from rice were economically viable and those from other crops were extremely high (Table 2).

- In scenario II, the CI was equal to $42.2 \%$, corresponding to the CI in 2010. This means that only part of the irrigation potential was exploited, although the investment in the development of irrigated schemes covered the whole set of parcels. According to this scenario, both rice and corn were cultivated at loss, whereas the other crops maintained their high economic viability (Table 3 ).

By multiplying the scenario II crops' NPV (Table 3) by the corresponding cultivated surface (Table 1), it was possible to calculate the NPVs over 20 years of exploitation of the S-SRV irrigated schemes. Figure 3 illustrates these NPVs. As it may be expected, the global NPV over 20 years of rice and corn harvests was negative. The global NPV from the irrigated schemes became negative as well (US\$-19.6 million); and the corresponding ERR was equal to $11.4 \%$.

\section{Sensitivity of the Model to Changes in Basic Assumptions}

In the preceding sections, it was assumed that the basic parameters for the rice production model corresponded to those indicated by the "official" sources. In this section the basic parameters were replaced by their median values from the available data sources from the S-SRV, see Manikowski 
TABLE 2 | Scenario I-The economic NPV and ERR of crops by hectare in the irrigated parcels of S-SRV assuming the $\mathrm{Cl}$ is equal to $100 \%$, in US dollars.

\begin{tabular}{lccccc}
\hline Years of project & $\mathbf{0}$ & $\mathbf{1}$ & $\mathbf{2}$ & $\ldots \ldots$ & $\mathbf{2 0}$ \\
\hline RICE & & & & & \\
Net revenue & $-\$ 6353$ & $\$ 1285$ & $\$ 1285$ & $\ldots$. & $\$ 2556$ \\
NPV & $\$ 3015$ & & & & \\
ERR & $19.8 \%$ & & & & \\
CORN & & & & & \\
Net revenue & $-\$ 6353$ & $\$ 38$ & $\$ 38$ & $\ldots .$. & $\$ 1309$ \\
NPV & $-\$ 5302$ & & & & \\
ERR & $-6.4 \%$ & & & & \\
ONION & & & & & \\
Net revenue & $-\$ 6353$ & $\$ 4329$ & $\$ 4329$ & $\ldots .$. & $\$ 5599$ \\
NPV & $\$ 23,314$ & & & & \\
ERR & $68.1 \%$ & & & & \\
TOMATO & & & & & \\
Net revenue & $-\$ 6353$ & $\$ 9596$ & $\$ 9596$ & $\ldots .$. & $\$ 10,867$ \\
NPV & $\$ 58,448$ & & & & \\
ERR & $151.1 \%$ & & & & \\
SWEET POTATO & & & & & \\
Net revenue & $-\$ 6353$ & $\$ 13,234$ & $\$ 13,234$ & $\ldots .$. & \\
NPV & $\$ 82,705$ & & & & \\
ERR & $208.3 \%$ & & & & \\
\hline
\end{tabular}

TABLE 3 | Scenario II-The economic NPV and ERR of crops per hectare in the irrigated parcels of $\mathrm{S}-\mathrm{SRV}$ assuming the $\mathrm{Cl}$ is equal to $42.2 \%$, in US dollars.

\begin{tabular}{lccccc}
\hline Years of project & $\mathbf{0}$ & $\mathbf{1}$ & $\mathbf{2}$ & $\ldots .$. & $\mathbf{2 0}$ \\
\hline RICE & & & & & \\
Net revenue & $-\$ 6353$ & $\$ 542$ & $\$ 542$ & $\ldots .$. & $\$ 1078$ \\
NPV & $-\$ 2006$ & & & & \\
ERR & $6.1 \%$ & & & & \\
CORN & & & & & \\
Net revenue & $-\$ 6353$ & $\$ 16$ & $\$ 16$ & $\ldots .$. & $\$ 552$ \\
NPV & $-\$ 5516$ & & & & \\
ERR & $-10.6 \%$ & & & & \\
ONION & & & & & \\
Net revenue & $-\$ 6353$ & $\$ 1827$ & $\$ 1827$ & $\ldots .$. & $\$ 2363$ \\
NPV & $\$ 6560$ & & & & \\
ERR & $28.6 \%$ & & & & \\
TOMATO & & & & & \\
Net revenue & $-\$ 6353$ & $\$ 4050$ & $\$ 4050$ & $\ldots .$. & $\$ 4586$ \\
NPV & $\$ 21,386$ & & & & \\
ERR & $63.7 \%$ & & & & \\
SWEET POTATO & & & & & \\
Net revenue & $-\$ 6353$ & $\$ 5585$ & $\$ 5585$ & $\ldots .$. & $\$ 6121$ \\
NPV & $\$ 31,623$ & & & & \\
ERR & $87.9 \%$ & & & & \\
\hline
\end{tabular}

(2015) for further details. The results (Table 4) show that the introduction of median values substantially affects the final results. Even the NPV from the rice cultivation with the

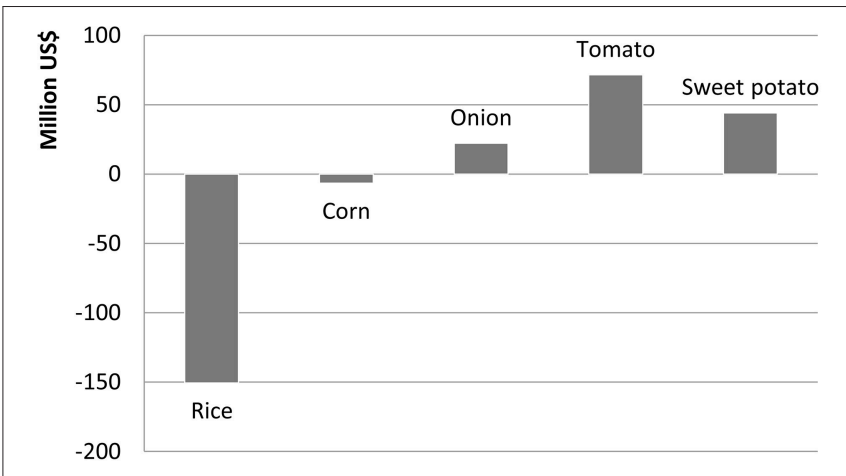

FIGURE 3 | Cumulative NPV over 20 years of the irrigation scheme in the S-SRV.

TABLE 4 | Base and median value inputs scenarios.

\begin{tabular}{|c|c|c|c|c|}
\hline \multirow[t]{2}{*}{ Parameters } & \multicolumn{4}{|c|}{ Scenarios } \\
\hline & \multicolumn{2}{|c|}{ Standard budget } & \multicolumn{2}{|c|}{ Median budget } \\
\hline \multicolumn{5}{|l|}{ ASSUMPTIONS } \\
\hline Paddy yield from hectare (tons) & \multicolumn{2}{|l|}{6} & \multicolumn{2}{|l|}{5.25} \\
\hline $\begin{array}{l}\text { Cost of construction of irrigated } \\
\text { scheme (US dollars per hectare) }\end{array}$ & \multicolumn{2}{|l|}{$6,353.2$} & \multicolumn{2}{|l|}{$11,126.0$} \\
\hline Cultural intensity & \multicolumn{2}{|l|}{$42.2 \%$} & \multicolumn{2}{|l|}{$37.6 \%$} \\
\hline \multicolumn{5}{|l|}{ RESULTS } \\
\hline \multicolumn{5}{|l|}{ RICE PRODUCTION } \\
\hline & NPV & ERR & NPV & ERR \\
\hline $\begin{array}{l}\text { One hectare with evaluated } \mathrm{Cl} \\
\text { (US\$) }\end{array}$ & -2006 & $6.1 \%$ & -7.543 & $-2.9 \%$ \\
\hline Whole irrigated schemes (US\$) & $-150,592,343$ & $6.1 \%$ & $-566,177,799$ & $-2.9 \%$ \\
\hline $\begin{array}{l}\text { Global crop production of the } \\
\text { irrigated schemes (US\$) }\end{array}$ & $-19,623,251$ & $11.4 \%$ & $-494,591,678$ & $1.3 \%$ \\
\hline
\end{tabular}

hypothetic $100 \%$ CI became negative, the NPV loss from the whole irrigated rice schemes exceeded 550 million US dollars, and the total loss from the S-SRV irrigated crop project over 20 years became close to 500 million; the EER was equal to $1.3 \%$.

In addition, Table 5 illustrates a sensitivity analysis for scenario I. The ERR is the most sensitive to changes in paddy yield, paddy price and CI, followed by parcel-creation cost, imported inputs and parcel maintenance. Producers have the largest margin in increasing the domestic labor remuneration, which, ceteris paribus, can increase by $112 \%$ and without decreasing the ERR below the $12 \%$.

\section{Other S-SRV Productions}

This section covers the known changes in productivity of other land uses in the S-SRV. They include modifications of flood recession lands, inland fishery shrinking, and reduction of pasture and forestlands. These changes were direct consequences of environmental modifications that followed the dams' construction on the Senegal River. 
TABLE 5 | Sensitivity analysis, switching values, and percent of change of the tested parameters needed to attain 12 and $0 \%$ of the ERR (scenario I).

\begin{tabular}{|c|c|c|c|c|}
\hline Parameter & $\begin{array}{l}\text { Base } \\
\text { value }\end{array}$ & ERR (\%) & $\begin{array}{l}\text { Switching } \\
\text { value }\end{array}$ & $\begin{array}{l}\text { Percent of } \\
\text { change (\%) }\end{array}$ \\
\hline \multirow[t]{2}{*}{ Cropping intensity $-\mathrm{Cl}(\%)$} & 100 & 12 & 65 & -35 \\
\hline & & 0 & 24 & -76 \\
\hline \multirow[t]{2}{*}{ Yield (t/ha) } & 6.0 & 12 & 5.1 & -15 \\
\hline & & 0 & 3.9 & -35 \\
\hline \multirow[t]{2}{*}{ Paddy price (US\$/t) } & 267 & 12 & 230 & -14 \\
\hline & & 0 & 181 & -32 \\
\hline \multirow[t]{2}{*}{ Parcel creation (US\$/ha) } & 6353 & 12 & 9800 & 54 \\
\hline & & 0 & 32,000 & 404 \\
\hline \multirow{2}{*}{$\begin{array}{l}\text { Cost of imported inputs } \\
\text { (US\$/ha/year) }\end{array}$} & 712 & 12 & 1166 & 64 \\
\hline & & 0 & 1742 & 145 \\
\hline \multirow[t]{2}{*}{ Cost of labor (US\$/ha/year) } & 390 & 12 & 874 & 124 \\
\hline & & 0 & 1604 & 311 \\
\hline \multirow{2}{*}{$\begin{array}{l}\text { Cost of parcel maintenance } \\
\text { (US\$/ha/year) }\end{array}$} & 610 & 12 & 1090 & 79 \\
\hline & & 0 & 1700 & 179 \\
\hline
\end{tabular}

\section{Recession Agriculture}

Each year, before the dams' construction, part of S-SRV was flooded for about 2 months by the end of the rainy season; after the water recession the wetted lands were cultivated. The flooded surfaces varied from 1 year to another according to the abundance of rains in the upper part of the Senegal River catchment. Between the 1946 and 1971, on average 65,000 ha per year of flooded plains were cultivated (DeGeorges and Reilly, 2006). After the Manantali dam's construction, the natural floods disappeared, but the opportunity to practice the recession agriculture on about 35,000 ha per year was maintained, thanks to the release of water from Manantali dam (OMVS, 2006). Traditionally, the recession plains were sown with sorghum, which generated the net benefit of US $\$ 110.7$ per hectare a year (Fall et al., 2009). The OMVS (2011) recommend sowing the SSRV controlled flood recession plains with rice, achieving a net benefit of US $\$ 161.5$ per hectare a year. Using these assumptions, the NPV of production loss from the recession agriculture was equal to US\$5.956 million over 20 years (Table 6).

\section{Pastures}

According to DeGeorges and Reilly (2006) the constructed dams and dikes reduced the S-SRV pasturelands from 80,000 to 4000 ha, which corresponds to the reduction of pasture feeding potential from 8928 to 446 tropical livestock units (TLU). The value of food provided by one TLU in semi-arid zones is about US\$ 85.6 per year $(F A O, 2007)$. Based on these assumptions, the NPV loss of pastures was approximately US $\$ 4.842$ million over 20 years of project. It is possible that the loss of some affected pasturelands could have been compensated by additional livestock production somewhere else in the valley, i.e., on pasturelands that were not affected by the consequences of damming the river. A similar effect might also have occurred for some of the impacted inland fishery and recession agriculture.
TABLE 6 | Incremental cost-benefit models for S-SRV natural resources productions impacted by changes in the S-SRV after the dams construction and the installation of irrigated schemes, in million US\$.

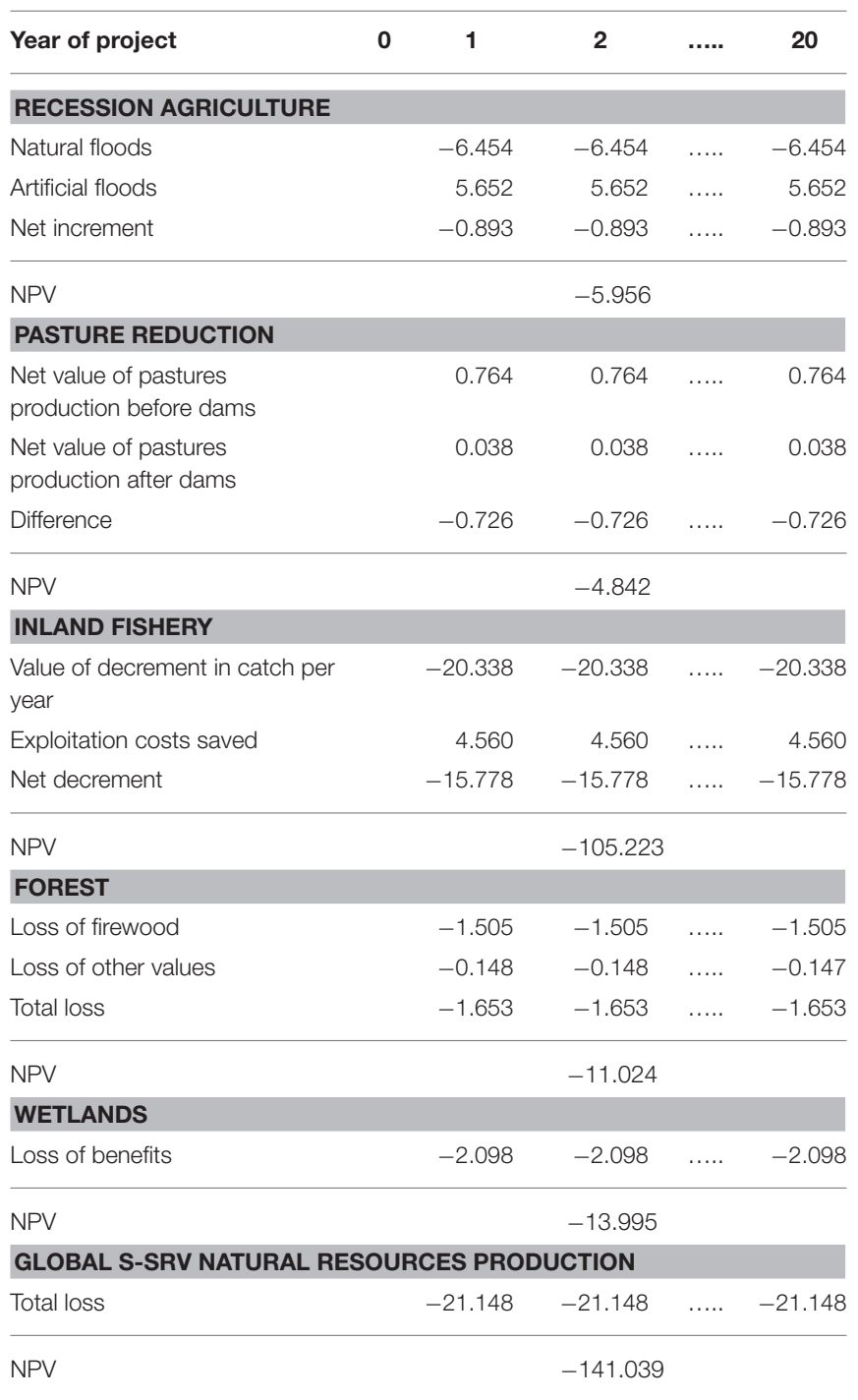

However, no reports about such developments were found in the available literature to date.

\section{Inland Fishery}

The construction of dams on the Senegal River reduced the fishing potential of the Senegalese part of the valley by about $75 \%$ in comparison to the situation in 1970 (Campredon, 1988). In particular, the floodplain fish catches were reduced from 32,000 tons in 1978 to between 6900 and 24,350 tons around 2006 (recalculated from DeGeorges and Reilly, 2006), which represents a median loss of 16,125 tons of fresh fish a year. The average catch of one boat in the S-SRV was estimated by OMVS (2010) at $8 \mathrm{~kg}$ of fish per day and its value in the landing place at US\$10.09. Using these data, the yearly loss of fish value in the S-SRV may be estimated at US\$20.338 million.

However, the loss of fish value was compensated by the economy on exploitation costs and material amortization which, 
for the non-motorized boats, was estimated at $2.4 \%$ of the catch value (Ly and Zein, 2009), and on remuneration for the fisherman, assumed to be of US\$2.02 a day. Using these data, the net loss for inland fishery represented US\$15.778 million a year, which corresponded to the loss of US $\$ 105.223$ million in terms of NPV over 20 years.

\section{Forested Surface}

According to DeGeorges and Reilly (2006), 8600 ha of forestlands were lost after the dams' construction. In Senegal, one hectare of forest produces approximately one ton of firewood per year (Hunter, 2012) of an average value of US\$175.0, recalculated from Ndiaye (2001). Another potential benefits from forests are the collection of fruits and herbs, which were estimated by IUCN (Ly and Zein, 2009) at US\$17.8 per hectare per year. Adding the loss of firewood and loss of other benefits, the global loss amounted to US\$1.653 million per year or US\$11.024 million in terms of NPV over 20 years.

\section{Loss of Productive Wetlands}

About 122,000 ha of wetlands were lost due to the absence and non-replacement of natural floods (recalculated from DeGeorges and Reilly, 2006). The benefit from one hectare of wetland in the S-SRV was estimated at US\$17.8 per year (Ly and Zein, 2009). Using these data, the yearly loss due to the wetlands reduction was US\$2.098 million, which results in US\$13.995 million NPV loss over 20 years.

\section{Global Loss of Natural Resources Production}

Adding the loss values from the considered S-SRV land used, the global loss over 20 years represented US $\$ 141.039$ million in terms of NPV (Table 6).

\section{Impacts on Health}

Water spills from the irrigation schemes and the presence of stagnant water throughout the year created favorable environment to the outbreak of waterborne diseases. Three of them, malaria, schistosomiasis (bilharzia), and diarrhea, had the major impact on health and wellbeing of the S-SRV population. The impact of these diseases is an issue beyond the economic costs associated with them. It also involves ethical aspects, human rights, changes in life expectancy, among other critical issues. However, for the purpose of this research, only approximate economic costs for medical treatment were included in the model.

\section{Malaria}

After the dams' construction, the presence of water for irrigation throughout the year multiplied the Anopheles mosquito reproduction sites and extended the malaria transmission period from the rainy season to the whole year (Diop and Jobin, 1994; Ficatier and Niasse, 2008). In addition, and more recently, the valley was recolonized by $A$. funestes a very important malaria vector, increasing thus the risk of malaria infection (Samb et al., 2012). According to OMVS (2003), malaria was at the origin of $90 \%$ of fevers and was the most important cause of death in the valley's region. The high malaria prevalence was also noted in other Senegal River valley countries, namely:
TABLE 7 | Population protection against Malaria.

\begin{tabular}{lccccc}
\hline Years of project & $\mathbf{0}$ & $\mathbf{1}$ & $\mathbf{2}$ & $\ldots .$. & $\mathbf{2 0}$ \\
\hline S-SRV population & $1,081,812$ & $1,108,424$ & $\ldots \ldots$ & $1,716,660$ \\
$\begin{array}{l}\text { Incremental protection cost } \\
\text { of whole population (US\$) }\end{array}$ & $1,806.621$ & $1,851,068$ & $\ldots \ldots$ & $2,886.822$ \\
\hline NPV (US\$) & & & & \\
\hline
\end{tabular}

$25 \%$ in Mauritania, and $15 \%$ in Mali (Diop and Jobin, 1994).

It should be noted that the link between development of irrigation and increase of malaria transmission is not yet well understood. Some authors consider that the extension of irrigation has little impact on malaria prevalence increase (Ijumba and Lindsay, 2001), whereas other authors report the absence of infected mosquitoes in the valley during the dry season (Touray et al., 2012).

To protect the whole Senegalese population against malaria, the government has prepared a National Strategic Plan for 2010-2015 (PNLP, 2013) that included provision of an antimalaria package, including drugs, nets, insecticides, and training. The PNLP estimated its cost at US\$3.14 per person a year, concerning the population protection for the wet season alone, when the mosquito presence is significant. However, in this paper, it was assumed that in the S-SRV, where mosquitoes are active also in the dry season, two interventions per year should be envisaged. Considering the anti-mosquito nets may be used longer than just a single season and that a supplementary training would not be needed, it was assumed that the incremental second round of anti-mosquito treatment during the dry season would cost approximately a half of the cost of the wet-season program (US\$1.67 per person). There is no consistent information available about the current number of malaria cases in Senegal, but the populations should be protected anyway, as a precautionary measure, particularly given the constant cases of malaria in neighboring countries.

The S-SRV population in 2010 was 1.081 million, growing $2.46 \%$ per year (OMVS, 2013a). Using these parameters, the incremental NPV of the anti-mosquito action over 20 years is equal to US\$64.8 million (Table 7).

Even treated, malaria may have other impacts on the infected person, such as global poor health, temporary loss of working ability, need of personal assistance, and/or school absenteeism. Nevertheless, the current available data for the assessed region are not yet sufficient to estimate these impacts accurately.

\section{Schistosomiasis}

Before the construction of Diama dam, only the urinary form of schistosomiasis was known from S-SRV (Talla et al., 1990; Campbell et al., 2010). However, in 1988, less than 2 years after the Diama's completion, the intestinal bilharzia was recorded in Richard Toll (currently with 90,000 inhabitants), where by the end of 1989 it reached epidemic proportions: $71.5 \%$ of its inhabitants infected (Talla et al., 1990; Diop and Jobin, 1994). 
TABLE 8 | S-SRV population protection and compensation for disability loss due to schistosomiasis, in US dollars.

\begin{tabular}{lccccc}
\hline Years of project & $\mathbf{0}$ & $\mathbf{1}$ & $\mathbf{2}$ & $\ldots . .$. & $\mathbf{2 0}$ \\
\hline $\begin{array}{l}\text { Cost of treatment of } \\
12.5 \% \text { of population }\end{array}$ & $2,855,982$ & $2,926,239$ & $\ldots .$. & $4,531,982$ \\
Value of the disability loss & $18,230,711$ & $18,679,186$ & $\ldots \ldots$ & $28,929,191$ \\
Total & $21,086,693$ & $21,605,426$ & $\ldots$. & $33,461,173$ \\
\hline NPV & \multicolumn{3}{c}{$378,334,744$} \\
\hline
\end{tabular}

There is no detailed study of the bilharzia prevalence and its impact on health in the S-SRV to date. Generally, it was reported that in the valley the infection rate was very high: approximately $50 \%$ only in Saint Louis (180,000 inhabitants; OMVS, 2003); between 75 and $100 \%$ of the S-SRV population in general (Sow et al., 2002; Ly and Zein, 2009); and between 90 and $100 \%$ among children in the S-SRV total population (Sid'Ahmed, 2013). Moreover, when urinary and intestinal bilharzia infects people from the same region, $50 \%$ of the infected individuals may suffer from the presence of both parasites (Senghor et al., 2014).

If not treated, schistosomiasis may also affect the ability of people to work (WHO, 2015). In Senegal, a parasitological survey of 857 randomly chosen individuals from the S-SRV have identified bladder morbidity caused by schistosomiasis among $83 \%$ of the studied population, liver fibrosis among $27 \%$, and both liver and bladder morbidity among 24\% (Meurs et al., 2012). According to Wright (1972), about 25\% of the Schistosoma's infected persons develop a disability that reduces their productive capacity. Salehe and Hassan (2012) suggested that disabled people with this type of infection work $24.4 \%$ of time less than nondisabled people, and that in Tanzania the medical treatment and care of an infected person costed US $\$ 21.12$ a year. In Senegal, the cost of treatment of one infection (consultation, diagnosis, and praziquantel medication) was about US\$2.91 per person (van der Werf et al., 2002).

In the model, it was assumed that before the dams' construction the bilharzia prevalence was close to zero in the SSRV population, whereas nowadays the whole S-SRV population is at risk of infestation and may consult a health center once a year at cost of US $\$ 2.91$ per visit. It was also assumed that $75 \%$ of S-SRV inhabitants were infected at least with one species of Schistosoma, and that $25 \%$ of the infested workers became disabled, working $24.4 \%$ of time less than a healthy worker. The remuneration for 1 day of work was US\$2.02 and a disability loss was equal to US\$0.244 a day. According to Index mundi (2015), in Senegal, $54.7 \%$ of the population is in working age (between 15 and 64 years). The data about the S-SRV population growth are the same as in the preceding section. Hence, using these parameters, in the S-SRV the NPV of loss due to schistosomiasis amounted to US\$378.3 million over 20 years (Table 8).

\section{Diarrhea}

In Senegal, 6.3\% of population suffer from diarrhea (Faye, 2014), but in the S-SRV it is the first reason for medical consultation in local health centers (Sid'Ahmed, 2013, p. 42). In this region, the
TABLE 9 | Cost of removal of invasive aquatic vegetation in the S-SRV.

\begin{tabular}{|c|c|c|c|c|c|}
\hline Year of project & 0 & 1 & 2 & $\ldots$. & 20 \\
\hline Canal border to clear (km) & & 5.5 & 5.5 & $\ldots \ldots$ & 5.5 \\
\hline Cost of clearing (US\$ per km) & & 18,000 & 18,000 & $\ldots \ldots$ & 18,000 \\
\hline Total cost per year (US\$) & & 99,000 & 99,000 & $\ldots \ldots$ & 99,000 \\
\hline
\end{tabular}

NPV (US\$)

$-669,245$

risk of diarrheal diseases increased due to the lack of adequate sewage system and insufficient drinking water supply (Diop and Jobin, 1994), along with an inadequate general hygiene and the excessive use of fertilizers and pesticides that contaminate the water sources used for domestic purposes (OMVS, 2003). The diarrhea incidence may increase even more, because of the recent appearance in the valley of Blastocystis sp., an aggressive diarrhea agent (El Safadi et al., 2014).

However, since there were no specific indicators allowing differentiating among the current situation and those before the dams' construction, the impact of the diarrhea diseases on the population was not included into the quantitative analysis, despite its importance.

\section{Environmental Impacts}

The main impacts of the dams and the irrigated agriculture on the environment may be classified as follows: invasion of water by aquatic vegetation; changes in the Djoudj National Bird Sanctuary $^{2}$; degradation of surface water quality; and changes in the Senegal River estuary.

\section{Aquatic Invasive Vegetation}

The aquatic vegetation was always present in the valley (OMVS/GEF, 2007), but its recent expansion was stimulated by the abundance of stagnant water throughout the year, as well as by the eutrophication process of water bodies, caused by their contamination with residues of fertilizers used for rice growing (OMVS, 2008). In 2001, 100,000 ha (24\% of the open water) were invaded by aquatic vegetation (OMVS, 2008) and the invasion progressed $10 \%$ a year in the subsequent years (OMVS, 2006).

This vegetation clogs the irrigation systems and, therefore, must be periodically removed. The cost of removing was of US $\$ 18,000$ per $\mathrm{km}$ (OMVS/GEF, 2007). Since the reinvasion occurs rapidly, the vegetation removal should be repeated every few years. According to the OMVS, in 2011, $5.5 \mathrm{~km}$ of canals have been cleaned from vegetation. It was assumed that, if the invasive vegetation expansion is not curbed, every year, $5.5 \mathrm{~km}$ of canals should be cleaned at a cost of US $\$ 49.500$ thousand per year; the NPV for 20 years of vegetation removal being equal to US\$669.2 thousand (Table 9).

\section{Djoudj National Bird Sanctuary}

The 16,000 ha Djoudj National Bird Sanctuary environment was modified by changes in the chemistry of water, invasion by the floating vegetation, and the regression of biodiversity

${ }^{2}$ The Djoudj National Bird Sanctuary is a World Heritage site by UNESCO situated in the Senegal River delta. 
(Diouf, 1988). The consequences were not yet quantified and, therefore, this impact was not included in the cost estimates of this sustainability assessment.

\section{Degradation of Surface Water Quality}

The presence of Diama dam and the associated dikes reduced the valley water flow velocity and its oxygenation. These effects, combined with the waste discharge from the surrounding villages and town, and the agrochemicals from the irrigated fields, have accelerated water eutrophication in the S-SRV (UNESCO, 2003). This impact was not yet quantified, and therefore not included in the calculations either.

\section{Changes in the Senegal River Estuary}

The presence of dams and the associated hydraulic structures have contributed to the ecological and socio-economic changes in the Senegal River estuary as well (Dumas et al., 2010). In 2003, to protect Saint Louis town against periodic floods, a 4-m wide channel was dug across a narrow spit of sand that blocked the flow of the river to the ocean. The channel rapidly widened reaching 2.4 kilometers in 2006 . As a result, the daily tidal range had a threefold increase (Mietton et al., 2007) and the estuary water salinity also increased, reducing the delta gardening, and threatening the remaining delta forest and pastures (Dumas et al., 2010).

\section{Social Impacts}

The salient social impacts of the S-SRV irrigated agriculture were regrouped in the following sections: (i) loss of cultivated land and change of agricultural practices, (ii) perturbation in the land tenure systems, and (iii) overpopulation in the proximity of irrigated schemes. The social impacts were not quantified yet, but the main ones are here described for qualitative purposes and to highlight their importance in the sustainability assessment.

\section{Loss of Cultivated Land and Change of Agricultural Practices}

After the dams' construction and the disappearance of natural floods, farmers deprived of their fields were offered to either move close to the irrigated schemes and start to grow irrigated rice or to migrate to areas that were artificially flooded by the release of water from the Manantali dam. The transition process was complex. Farmers who decided to switch to irrigated agriculture faced the problem of assimilation of new technologies and the availability of credit for inputs and equipment (Mokanzo, 2000; Fraval et al., 2002). Those who preferred to cultivate under the artificial recession regime were exposed to the irregularity of the artificial flooding (DeGeorges and Reilly, 2006). The impacts of these changes on the well-being of the displaced farmers were not yet quantified.

\section{Land Tenure}

The S-SRV lands are mostly used for agriculture and livestock husbandry, usually practiced by the transhumant populations. By damming the river, the disappearance of flood and the expropriation of landowners from areas sequestered for irrigation perturbed the customary arrangements among the land
TABLE 10 | Total economic NPV of the Senegal River damming and S-SRV irrigated schemes exploitation in millions of US dollars.

\begin{tabular}{lcc}
\hline Production or impacts & NPV & \% of total NPV \\
\hline Irrigated schemes production & -19.623 & 3.4 \\
Other productions & -141.039 & 24.7 \\
Human health & -410.749 & 71.3 \\
Environment (partially included) & -0.660 & 0.1 \\
\hline Total NPV & -572.071 & \\
\hline
\end{tabular}

users, leading to conflicts and uncertainty (Salmone, 1998). This impact was also not duly quantified to date.

\section{Overpopulation}

Three times more people are now living in the S-SRV than in the 1960s, whereas the water flow in the Senegal River now represents only half of the average flow between 1950 and 1970 (OMVS, 2012). The quantity of water reduction in conjunction with the population increase, water pollution and eutrophication represent a potential source of future impacts on the population health, and environment.

\section{Overall Impacts of the S-SRV Dams and Irrigated Rice Schemes}

Table 10 summarizes the NPVs of the global S-SRV irrigation project. All the LCA components were highly expensive for the Senegal's economy. The total loss expressed in NPV terms over 20 years of the project's model duration attained US\$-572.1 million. This loss did not include the identified, but not yet quantified impacts such as those described in sections Environmental Impacts and Social Impacts. If the cost-benefits from the irrigated schemes were calculated using the median values of the reports concerning the basic parameters, instead of the "official" ones, the global NPV loss over 20 years would be much higher.

\section{DISCUSSION}

In light of the results presented in this study, the rice cultivation in the S-SRV irrigated schemes was not economically feasible, and the irrigation dam system presented major negative impacts on human health, social welfare, and the surrounding environment. The concerns expressed about the S-SRV rice irrigation, cited in the introduction of this study, were duly justified by the cost-benefit analysis. Similarly, Shah et al. (2002) had also warned about the major risks involved in the sustainability of irrigation systems from precarious governmental planning and management, particularly in developing nations with limited funding resources.

\section{Feasibility of Irrigated Agriculture}

In conformity with the GOANA (2008) and SAED (2009a) assurances, the results of our evaluation show that the irrigated rice growing in the S-SRV was financially beneficial to the farmers (Table 1). However, this benefit was achieved at the expenses of the country's economy and major environmental and social 
impacts. If one takes into account the cost of construction of the S-SRV irrigated schemes and the practiced $\mathrm{CI}$ at the scale of the whole S-SRV irrigated schemes, the rice growing represents an ERR of $6.1 \%$ and the NPV loss of US $\$ 178.4$ million (Table 4). When one replaces the government's assumptions by the medians from S-SRV reports the ERR falls to $-2.9 \%$ and the NPV falls to US\$-752.9 million (Table 4). Moreover, the irrigated-rice production required foreign currency inputs for the purchase of equipment and energy for the construction of irrigated schemes, production inputs, and fuel for water pumping for irrigation. The economic loss from the irrigated rice production reduces the expected economy in foreign currency spending for imported rice that was one of the objectives of the irrigated rice development policies.

The government has expected (PRACAS, 2015a,b,c) that the expansion of the domestic production of rice would reduce its imports. However, this expansion was not sufficient to avoid even higher rice imports in the last decades (Figure 1). In fact, independently of the Senegalese population growth, the rice imports growth was stimulated by the preference of the urban consumers for the imported rice, since they often considered the local rice was inadequately de-husked, poorly cleaned, and sorted (FAO, 2010; Demont and Ndour, 2014). As Rizzotto and Demont (2010) previously noticed, the rice development programs were concentrated on production increase, whereas there was no sufficient support for quality improvements. Consequently, the local rice still occupies a minor share in the local rice market (Africa Top Successes, 2015).

In parallel to the heavy losses on irrigated rice (and corn), the model indicates high economic returns (ERRs ranged from 28.6 to $87.7 \%$ ) from the S-SRV irrigated schemes cultivated with onion, tomato, and sweet potato (Table 3 ). The diversification of the produced crops and investment in their transformation and commercialization seems to be an obvious way for the economic viability. Senegal has a long tradition of tomatoes and other horticulture production exports (Matsumoto-Izadifar, 2015). For example, the industrial tomato has been cultivated in Senegal and exported since 1990s (Ministère de l'Agriculture et de l'Hydraulique, 2005).

Nevertheless, it seems that the policy option of producing local rice for urban consumers and spare foreign currency expense was so dominant among the Senegal's rural policy planners that it obscured the opportunity of using the S-SRV irrigated schemes for other more economically feasible productions.

\section{Externalities}

Only few years after the dams' construction it appeared that the changes in the hydric regime of the river have triggered a long series of disturbances (Ndao, 1999; UNESCO, 2003; DeGeorges and Reilly, 2006; OMVS, 2008, 2012; KfW BEI AFD, 2009), which can be classified into the following categories: (i) modifications of natural environment, (ii) health problems, and (iii) negative social impacts. According to Tayaa et al. (2005), the fundamental causes of these disturbances were the changing rainfalls, the inefficient irrigation technology, the demographic growth, urbanization and poverty, and the lack of appropriate governance.

\section{Environment}

FAO (2003) suggests that the main environmental constraints developed through the S-SRV irrigated schemes project can be described as follows: (i) strong pressure on land; (ii) water salinization and alkalization; (iii) lack of drainage; (iv) pollution of soils and groundwater by agricultural inputs; (v) deficient irrigation infrastructure management; (vi) loss of vegetation cover and ecosystems degradation; (vii) strong competition between agriculture and transhumant herding for land; and, finally, (viii) low quality irrigated schemes and canals construction works. Despite the existence of some papers earlier discussed about the environmental issues of the S-SRV, very little or nothing was done to take appropriate mitigation action so far.

The past efforts to mitigate the unwanted consequences of construction and exploitation of the irrigated schemes were limited to the application of palliative measures (e.g., removing invasive vegetation and better management of artificial floods). The lasting and the efficient handling of the impact of the SRV irrigated rice project require dealing with the underlying causes of the present unwanted situation.

\section{Impacts on Health}

Even using very conservative figures as inputs for the model, the impact of the irrigation schemes on human health (NPV equals US\$-410.7 million) represents the most important component of the total impact. The past efforts of reducing malaria, schistosomiasis, and diarrheas incidences were organized according to the fund availability. For example, in the past years World Bank distributed some waterborne disease prevention drugs, anti-mosquito nets (World Bank, 2014) and improved drinking water supply in one locality (Faye and Bah, 2013). Obviously, health protecting and diseases reduction sporadic efforts should not replace a program, which is still lacking for the valley, particularly one based on integrated vector management and evidence based decision making, as also noted by the WHO (2004).

\section{Social Impacts}

In the S-SRV, the most devastating social event associated with the river damming was the 1989 conflict between Mauritanian and Senegalese populations of the river valley that culminated by deportations and influx of about 80,000 refugees in both side of the Senegal River (Salmone, 1998). Although the land tenure problem was relatively settled and the compensation scales for the resettled peoples were recently agreed in consultation with the involved communities (OMVS, 2013b), the attribution of land to farmers, clarification of the transhumance passage, and attribution of pastures exploitation rights still require further formal and participatory agreed regulations.

Search for new land for agriculture and husbandry for the valley population is a growing problem that can be solved by increasing opportunities for the recession agriculture (Fraval et al., 2002; Saarnak, 2003). Intensification and diversification of the irrigated agriculture on the expense of the rice production may be another opportunity, as well as the use of other agricultural technologies and irrigation systems, preferably under professional agronomical assistance. 


\section{Policy}

The findings obtained in this paper suggest that the past Senegal rice growing policies (the GOANA and PNAR) were not economically feasible. The PNAR policy stated that the development of rice production was "to satisfy the local needs and substitute for imported rice" (Gouvernement du Sénégal, 2010, Art. 3), but the application of this and other policies did not reduce the rice import and the self-sufficiency objective by 2012 was not achieved, as further discussed below.

\section{Policy Rationale}

The results of this study points to the inadequate rationale behind the past S-SRV irrigated rice production policies. Namely, the policies did not properly take into account the costs of the irrigated schemes, the paddy yields and the past values of the CI. Paddy price paid to farmers did not correspond to its market value, but it was fixed every year by a parastatal body. The impacts on environment and the human costs were not taken into account either. Additionally, the planners have apparently not changed their strategies in spite of difficulties in implementation of the earlier policies. A clear example is the newly launched policy targeting at the national rice production autonomy by 2017, requiring a local production about three times higher than that in 2012, a goal that may be difficult to reach (USDA Foreign Agricultural Service, 2015; see also Figure 1).

\section{Policy Justification}

The promotion of S-SRV irrigated rice development and the simultaneous lack of interest in improvement of the living conditions of the valley populations may be regarded as a classic example of the "urban bias" (Lipton, 1977). This bias consists on taking decisions in favor of the urban citizens composed of the electorate better educated, more politically involved and able to lobbying the policymakers more efficiently than rural population. The government's support of the S-SRV irrigated rice production project aimed to satisfy the dominantly rice consumed population of urban centers. This policy along with the urban biased distribution of hydropower generated by the Senegal River dams (Fraval et al., 2002) might be interpreted as a political will to satisfy the urban population on the well-being expenses of the S-SRV population.

\section{Equity}

The decision to create the S-SRV irrigated rice schemes did not respect the principle of equity, which can be understood as "...fairness and social justice and of greater access to a better quality of life" (UNDP, 2011, p. IV). The design and the implementation of the schemes were not properly discussed with the valley's population (Ndao, 1999). The process of redistribution of lands after the creation of the irrigation parcels was a source of frustrations to farmers and of conflicts among the farmers and herders (Salmone, 1998). The inadequate management of water release from Manantali dam designed to create the artificial floods in replacement of the natural ones was at the origin of crop failures (Adams, 2000); it seems that farmers were not compensated for the incurred loss.
Only in 2002, the OMVS approved the Water Charter, permitting the participation of outside observers in the OMVS; however, the observer status request should be approved by both the OMVS High Commissioner and the council of ministers of the member countries (Vick, 2006). Furthermore, national cells (cellules nationales) created by OMVS after 2002 were charged to transfer the farmers' requests to the national and regional OMVS offices, but their efficiency was questioned (Sall, 2009). Hence, further efforts are needed to achieve satisfactory level of equity for the S-SRV population.

\section{Ethical Consideration}

From a human rights perspective, the policy is unjustified while paradoxically advocating modernization and development, but violating or overriding the important human rights of the local population (FAO, 2004). In this light, it may be considered as ethically inappropriate to maintain a policy that aimed to so drastically reduce the well-being of a fraction of the country population (the S-SRV population) to the benefit of the overall country's economy or other part of its citizens.

\section{CONCLUSIONS}

The exploitation of the irrigated schemes represents the potential high returns from the production. However, this study has shown that if inappropriately constructed and exploited, they become the origin of economic loss and the source of major impacts on human health and the environment. Before continuing the S-SRV irrigated rice production project, the Senegalese government and the OMVS should consider, as a priority for urgent action, to ensure the economic viability of the project, restore the environmental sustainability, and protect the health and wellbeing of the local population. To this end, the program requires a complete revision and restructuration of its initial scope. This revision and restructuration may be done based on an exhaustive set of independently collected quantitative data, covering the economy, the environment, and human welfare facets of the project and its impacts, under a Life-Cycle Assessment (LCA) approach. To ensure transparency and high quality of the result, the study should be done by an independent body and discussed with stakeholders.

The development of the S-SRV irrigation schemes was possible thanks to the assistance of donors, who first co-financed the dams construction, then the associated infrastructures and finally the preparation of the irrigation systems. It seems to be fully justifiable to consider that they are co-responsible for the present situation, particularly for the social and environmental liabilities. Therefore, they should also contribute to mitigate the impacts already caused on the valley and ensure a healthy environment to the population. For this purpose, an independent auditing scheme and in open access could bring more credibility and transparence to the process.

The SRV experience shows that the irrigated schemes using flooding systems can present major health risks when no precautionary measures are taken, particularly in critical zones of tropical countries. To reduce the risks of additional mosquito infestation, the villages and towns should preferably avoid direct 
proximity to the paddy fields. Further, to prevent spreading of bilharzia, the population should be warned from the use of irrigation canals for recreation and drinking water supply. Finally, to avoid the diarrhea and poisoning by pesticides and fertilizer residues, the drinking water sources should be adequately protected from contamination. The costs associated with the adequate management of irrigated rice fields should be included into the project's investment costs.

The results of this study have shown that the exploitation of economically successful irrigated schemes requires the development of new rules of coexistence among the land used for the irrigation, the natural environment and human settlements. The paper shows the need for an integrated approach in future development interventions, and prompt policy makers to assess the projects in a wider perspective and with a whole-system view.

\section{REFERENCES}

Adams, A. (2000). The Senegal River: Flood management and the Future of the Valley. Available online at: http://pubs.iied.org/pdfs/7419IIED.pdf (Accessed September 19, 2015).

Africa Top Successes (2015). Senegal: Macky Sall Calling for the Local Rice Consumption. La Rédaction. Available online at: http://www. africatopsuccess.com/en/2015/03/17/senegal-macky-sall-calling-for-thelocal-rice-consumption/ (Accessed September 15, 2015).

Belli, P., Anderson, J. R., Barnum, H. N., Dixon, J. A., and Tan, J.-P. (2001). Economic Analysis of Investment Operations Analytical Tools and Practical Applications. Washington, DC: WBI Development Studies; World Bank Institute.

Buisse, T., Maume, J.-P., and Gassama, M. (2011). The use of hydraulic models to optimist the rehabilitation of an open vhannel irrigation system: the example of the Senegal river delta irrigation system. Irrig. Drain. 60, 308-317. doi: 10.1002/ird.581

Campbell, G., Noble, L. R., Rollinson, D., Southgate, V. R., Webster, J. P., and Jones, C. S. (2010). Low genetic diversity in a snail intermediate host (Biomphalaris pfeifferi Krass, 1848) and schistosomiasis transmission in Senegal River Basin. Mol. Ecol. 19, 241-246. doi: 10.1111/j.1365-294X.2009.04463.x

Campredon, P. (1988). "Pêche artisanale et conservation du littoral de la Mauritanie et à la Guinée Bissau," in Strategies for Wise Use of Wetlands: Best Practices in Participatory Management, Proceedings of Workshop Held at the $2^{\text {nd }}$ International Conference on Wetlands and Development (November 1988, Dakar, Senegal), Global series 8, ed M. Gawler (Wetlands International). Available online at: http://www.wetlands.org/Portals/0/ publications/Questionnaire/WI_WiseUseWetlands_2002.pdf (Accessed April 19, 2015).

CGERV (2012). Analyse Économique Diagnostic de la Filière RIZ - Campagne Hivernale RIZ 2011-2012 Diagnostic de la Filière riz, $N^{\circ} 8$. Available online at: https://lavoixdelavallee.files.wordpress.com/2012/10/ae-riz-hiv-11_ 12-cgerv.pdf (Accessed June 24, 2015).

DeGeorges, A., and Reilly, B. K. (2006). Case Study for 2006 HDR Dams \& Large Scale Irrigation on the Senegal River Impacts on Man \& the Environment. UNDP Human Development Report 2006. Available online at: http://hdr.undp.org/ sites/default/files/degeorges_andre.pdf (Accessed September 14, 2015).

Demont, M., and Ndour, M. (2014). Upgrading Rice Value Chains: Experimental Evidences from 11 African Markets. Global Food Security. Available online at: $\quad$ http://www.sciencedirect.com/science/article/pii/S2211912414000418 (Accessed April 30, 2015).

Dieng, A., and Gueye, A. (2005). Revue des Politiques Agricoles au Sénégal: Bilan Critique de Quarante Années de Politique Céréalière. Available online at: http:// www.bameinfopol.info/IMG/pdf/Revue_Dieng_et_Gueye.pdf (Accessed April $14,2015)$.

\section{AUTHOR CONTRIBUTIONS}

SM led the development of this paper as part of his thesis carried out at SOAS, and from his previous professional experiences in the assessed region. AS contributed with the research supervision, analysis and paper reviews.

\section{ACKNOWLEDGMENTS}

The authors acknowledge SOAS (University of London) for the use of original contents presented in the thesis recently defended by the first author (Manikowski, 2015), and Imperial College London for supporting the publication of this article in open access. They also appreciate the valuable comments made by the paper reviewers and editor.

Diop, M., and Jobin, W. R. (1994). Senegal River Bassin Health Master Plan Study. Washington, DC: USAID. Water Sanitation for Health Project No. 936-5973.

Diouf, M. (1988). "Djoudj National Park and its periphery: an experiment in wetland co-management," in Strategies for Wise Use of Wetlands: Best Practices in Participatory Management, Proceedings of Workshop Held at the 2nd International Conference on Wetlands and Development (November 1988, Dakar, Senegal), Global series 8, ed M. Gawler (Wetlands International). Available online at: http://www.wetlands.org/Portals/0/ publications/Questionnaire/WI_WiseUseWetlands_2002.pdf (Accessed April 7, 2015).

Dumas, D., Mietton, M., Hamerlynck, O., Pesneaud, F., Kane, A., Coly, A., et al. (2010). Large dams and uncertainties. the case of the Senegal River (West Africa). Soc. Nat. Resour. 23, 1108-1122. doi: 10.1080/08941920903 278137

EDRC (1997). Guidelines for the Economic Analysis of Projects. Asian Development Bank. Available online at: http://iappta.fao.org/iapptafaoimg/file/ Guidelines\%20for\%20economic\%20analysis\%20-\%20ADB\%20.pdf (Accessed July 1, 2015).

El Safadi, D., Gaayeb, L., Meloni, D., Cian, A., Poirier, P., Wawrzyniak, I., et al. (2014). Children of Senegal River Basin show the highest prevalence of Blastocystis sp. ever observed worldwide. BMC Infect. Dis. 14:164. doi: 10.1186/1471-2334-14-164

Fall, A. A., Lagnane, O., and Ndiaye, A. (2009). La Chaîne de Valeur Milesorgho: Otions Stratégiques de Développement au Sénégal. CNC/Sénégal; USAID/Wula Nafta. Available online at: http://pdf.usaid.gov/pdf_docs/PA00JWXT.pdf (Accessed September 4, 2015).

FAO (2003). Sénégal Programme National d'appui à la Sécurité Alimentaire (Programme de Relance des Productions Vivrières). Available online at: http:// www.bameinfopol.info/IMG/pdf/PROGRA_1.pdf (Accessed June 24, 2015).

FAO (2004). The Ethics of Sustainable Agriculture Intensification. Available online at: http://www.fao.org/docrep/007/j0902e/j0902e00.HTM (Accessed June 26, 2015).

FAO (2007). Pastoralisme et Gestion des Parcours. Available online at: http://www. fao.org/docrep/014/i1861f/i1861f10.pdf (Accessed June 29, 2015).

FAO (2010). Aperçu du Développement Rizicole. Available online at: http://www. fao.org/fileadmin/user_upload/spid/docs/Senegal/Riziculture_etatdeslieux_ SN.pdf (Accessed February 27, 2015).

FAO (2015). The Practice of Irrigation 1.1 The Perspective and Objectives of Irrigation. Available online at: (Accessed July 22, 2015).

FAOSTAT (2015). UN FAO Statistics Division. Available online at: http://faostat3. fao.org/download/P/*/E (Accessed March 19, 2015).

Faye, M. M., and Bah, C. S. (2013). Rapport d'Achèvement (RdA) du PGIR 1). Available online at: http://cda.portail-omvs.org/sites/cda.portail-omvs.org/ files/sites/default/files/fichiers_joint/14314_rapport_achevement_pgire_i_ rda_juillet_2013.pdf (Accessed March 17, 2015). 
Faye, S. (2014). Non-price determinants for Health Care Services in Senegal. Afr. Dev. Rev. 26, 38-49. doi: 10.1111/1467-8268.12062

Ficatier, Y., and Niasse, M. (2008). Volet Social et Environnemental du Barrage de Manantali Évaluation Rétrospective. AFD Département de la Recherche, Division Évaluation et capitalisation, Agence Francaise de Développement, Paris.

Fraval, P., Bader, J.-C., Mané, L. K., David-Benz, H., Lamagat, J.-P., and Diagne, D. O. (2002). "The quest for integrated and sustainable water management in the Senegal River Valley," in ENVIROWATER 2002. 5ème Conférence InterRégionale sur l'Environnement et l'Eau. Ouagadougou Burkina Faso. Available online at: http://agritrop.cirad.fr/511230/1/document_511230.pdf (Accessed June 14, 2015).

Gannett, F., Corddry, and Carpenter Inc. (1978). Evaluation des Effets sur L'environnement D'aménagements Prévus Dans le Bassin du Fleuve Sénégal, Vol. 20 (Dakar: OMVS). Available online at: http://cda.portail-omvs.org/ sites/cda.portail-omvs.org/files/sites/default/files/fichiers_joint/10104-ocr.pdf (Accessed June 19, 2015).

Gittinger, J. P. (1966). Economic Analysis of Agricultural Projects. Baltimore, MD: John Hopkins.

GOANA (2008). Cahier D’un Projet D'investissement. Goana: Ministère de l'Agriculture. Available online at: http://www.pds.sn/IMG/pdf/5_Realisation_ projet_goana.pdf (Accessed February 1, 2015).

Goodman, C. A., Coleman, P. G., and Mills, A. J. (1999). Cost-effectiveness of malaria control in sub-Saharan Africa. Lancet 354, 378-385. doi: 10.1016/S0140-6736(99)02141-8

Gould, M. S., and Zobrist, F. A. (1989). An overview of water resources planning in West Africa. World Dev. 17, 1717-1722. doi: 10.1016/0305-750X(89) 90195-2

Gouvernement du Sénégal (2010). Arrêté Ministériel n ${ }^{\circ} 5042$ MA en Date du 8 Juin 2010. Dakar: Journal Officiel du Sénégal. Available online at: http://www.jo. gouv.sn/spip.php?article8708 (Accessed June 17).

Hunter, R. (2012). Improved Cooking Stove Program (Senegal). Calculating the National Non-Renewable Biomass Fraction. Cape Town: C4 EcoSolution. Available online at: http://cdm.unfccc.int/filestorage/q/ u/P90SLG14MH78B3XZWQCYFEUDNA65OK.pdf/baseline3.pdf?t= b2Z8bnJxdWhtfDDA5GMOSP4Ny3nilafb0WMl (Accessed June 6, 2015).

Ijumba, J. N., and Lindsay, S. W. (2001). Impact of irrigation on malarial in Africa: paddies paradox. Med. Vet. Entomol. 15, 1-11. doi: 10.1046/j.13652915.2001.00279.x

Index mundi (2015). Senegal Age Structure. Available online at: http:/indexmundi. com/Senegal/age_structure.html (Accessed July 4, 2015).

IRRI - International Rice Research Institute (2015). World Rice Statistics Online Query Facility. Available online at: http://ricestat.irri.org:8080/wrs2/entrypoint. htm (Accessed January 2, 2016).

KfW BEI AFD (2009). Evaluation Ex Post Conjointe. Le barrage Manantali. Frankfort. Available online at: http://www.oecd.org/countries/senegal/ 44665007.pdf (Accessed June 27, 2015).

Khouma, M. (2011). Étude sur la Vulnérabilité de L’agriculture Irriguée et de Lélevage dans la Valée du Fleuve Sénégal. Ministère de l'Environnement et de la protection de la nature Japan and UNDP. Available online at: http://www.denv. gouv.sn/documents/Projet_INTAC/VERSION\%20FINALE\%20RAPPORT \%20AGRICULTURE\%20IRRIGUEE\%20-\%20Juin\%2011.pdf (Accessed March $24,2015)$.

Lipton, M. (1977). Why Poor People Stay Poor: Urban Bias in World Development. Cambridge, MA: Harvard University Press.

Ly, K. O., and Zein, S. O. A. M. (2009). Évaluation Économique D'une Zone Humide: Le Cas de Diawling, Mauritania. Gland: IUCN. Available online at: https://portals.iucn.org/library/efiles/documents/2009-018.pdf (Accessed March 24, 2015).

Manikowski, S. (2015). Cost-benefit of Irrigated Agriculture and its Externalities: Case of the Senegal Part of the Senegal River Valley. MSc dissertation, SOAS, University of London, 72p.

Matsumoto-Izadifar, Y. (2015). Available online at: http://www.oecd.org/ countries/senegal/41302267.pdf (Accessed May 18, 2015).

Meurs, L., Mbow, M., Vereecken, K., Menten, J., Mboub, S., and Polman, K. (2012). Bladder morbidity and Hepatic fibrosis un mixed Schistosoma haematobium and S. mansoni infections: a population-wide study in Northern Senegal. PLoS Negl. Trop. Dis. 6:e1829. doi: 10.1371/journal.pntd.0001829
Mietton, M., Dumas, D., Hammerlynk, O., Kane, A., Coly, A., Duvail, F., et al. (2007). Water management in the Senegal River Delta: a continuing uncertainty. Hydrol. Earth Syst. Sci. Discuss. 4, 4296-4323. doi: 10.5194/hessd4-4297-2007

Ministère de l'Agriculture (1985). Rôle et Activités de la SAED dans le Développement Rural des Vallées du Fleuve Sénégal et de la Faleme (Note de synthèse). Available online at: http://cda.portail-omvs.org/sites/cda. portail-omvs.org/files/sites/default/files/fichiers_joint/9234_ocr.pdf (Accessed February 17, 2015).

Ministère de l'Agriculture (2009). Programme National D'autosuffisance en riz Stratégie Nationale de Développement de la Riziculture. Available online at: http://www.jica.go.jp/english/our_work/thematic_issues/agricultural/pdf/ senegal_en.pdf (Accessed June 17, 2015).

Ministère de l'Agriculture (2010). Arrêté Ministériel $n^{\circ} 5042$ MA en Date du 8 Juin 2010. Available online at: http://www.jo.gouv.sn/spip.php?article8708 (Accessed February 17, 2015).

Ministère de l'Agriculture et de l'Hydraulique (2005). La Culture de la Tomate Industrielle Dans La Valée du Fleuve Sénégal: Acquis et Perspectives. Available online at: http://hubrural.org/IMG/pdf/senegal_tomate_industrielle_dec2005. pdf (Accessed June 5, 2015).

Mokanzo, T. (2000). Gestion Financière des Périmètres Irrigués du Delta du Fleuve Sénégal Le cas de GIE de Producteurs Agricoles de Thiagar. Rapport de stage, DESS Analyse Économique du Développement Université De ParisX Nanterre. Available online at: http://horizon.documentation.ird.fr/exl-doc/ pleins_textes/num-dakar-02/010023489.pdf (Accessed June 17, 2015).

Ndao, A. (1999). Water Resources Integrated Management: The Case of the Senegal River Basin. Dakar.

Ndiaye, A. (2001). 'Expériences du PERACOD: Promotion des Combustibles Domestiques Alternatifs.' FORUM CSAO 2011 'L'Afrique de l'Ouest et le Brésil Face aux Enjeux des Énergies Renouvelables' 5-6 Décembre 2011. Available online at: http://www.oecd.org/fr/pays/senegal/49257976.pdf (Accessed February 17, 2015).

OMVS (2010). Caractérisation de la Pêche Continentale Dans la Région de Matam. Available online at: http://cda.portail-omvs.org/sites/cda.portail-omvs.org/ files/sites/default/files/fichiers_joint/13264_etude_caracterisation_peche_ continentale_matam_rapport_finale_novembre_09.pdf (Accessed May 5, 2015).

OMVS/GEF (2007). Transboundary Diagnostic Environmental Analtysis of the Senegal River Basin. Regional Synthesis. Available online at: http://iwlearn.net/ iw-projects/1109/reports/transboundary-diagnostic-environmental-analysisof-the-senegal-river-basin (Accessed July 13, 2015).

OMVS, c. (2015). Les Journalistes de la Vallée Visitent les Ouvrages de l'OMVS et se Félicitent de Limportance des Investissements Pour Restaurer L'hydro Système du Fleuve. Available online at: http://www.portail-omvs.org/actualite/ journalistes-vallee-visitent- ouvrages-lomvs-et-se-felicitent-limportance-des (Accessed July 13, 2015).

OMVS (2003). Senegal River Basin in Guinea, Mali, Mauritania, Senegal. UNESCO WWDR First Water Development Report. Available online at: http://webworld.unesco.org/water/wwap/case_studies/senegal_river/senegal_ river.pdf (Accessed June 19, 2015).

OMVS (2006). Plan de Gestion des Pestes et des Pesticides (PGPP). E 1312. Available online at: http://cda.portail-omvs.org/sites/cda.portail-omvs.org/files/sites/ default/files/fichiers_joint/2006-ef0041-crd_0.pdf (Accessed February 16, 2015).

OMVS (2008). Plan d'Action Stratégique de Gestion des Problèmes Environnementaux Prioritaires du Bassin du Fleuve Sénégal, 123. Available online at: http://cda.portail-omvs.org/sites/cda.portail-omvs.org/files/sites/ default/files/fichiers_joint/13249.pdf (Accessed February 5, 2015).

OMVS (2011). SDAGE du Fleuve Sénégal Phase 3, Schéma Directeur, Version Définitve. Available online at: http://portail-omvs.org/sites/default/ files/fichierspdf/rapport_sdage_phase_3_drfinitif.pdf (Accessed May $5,2015)$.

OMVS (2012). Élaboration de la Nomenclature des Seuils d'Autorisation et de Déclaration des Prélèvements d'Eau du Fleuve Sénégal. Rapport Final (Version Provisoire). Dakar: OMVS.

OMVS (2013a). Évaluation Régionale Startégique (ERS) des Options de Développement Hydroéletrique et des Ressources en Eau Dans le Bassin Fleuve Sénégal. Dakar: OMVS. 
OMVS (2013b). Actualisation du Cadre de Politique de Réinstallation (CPR) Rapport Final. RP1451. Available online at: http://www.portail-omvs.org/sites/ default/files/publications/files/pgire_2-pgire_ii_cpr_vf-diong.pdf (Accessed February 17, 2015).

Pearce, D., Atkinson, G., and Murato, S. (2006). Cost-Benefit Analysis and the Environment: Recent Developments. Paris: OECD Publishing.

PNLP (2013). Lutte Contre le Paludisme au Sénégal, L'histoire d'un Partenariat Réussi. Available online at: http://issuu.com/speakupafrica/docs/partnership_ story_fr (Accessed July 13, 2015).

PNUE (2005). Évaluation Intégrée de Limpact de la Libéralisation du Commerce. Une étude de cas sur la filière du riz au Sénégal, PNUE Châtelaine Genève Suisse, ISE-UCAD Dakar Sénégal. Available online at: http://www.unep.ch/etb/ publications/intAssessment/Senegal.pdf (Accessed February 17, 2015).

Potts, D. (2002). Project Planning and Analysis for Development. Boulder, CO; London: Lynne Rienner Publishers Inc.

PRACAS (2015a). Remise des Documents du PRACAS au Ministre de l'Agriculture et de l'Equipement Rural. Available online at: http://www.fao.org/senegal/ actualites/detail-events/fr/c/293376/ (Accessed July 13, 2015).

PRACAS (2015b). Discours du président de la République. Available online at: http://www.gouv.sn/Discours-du-president-de-la, 1823.html (Accessed July 13, 2015).

PRACAS (2015c). Réunion de Partage des Résultats du PSE. Available online at: http://www.dakaractu.com/Reunion-de-partage-des-resultats-duPSE-allocution-du-president-Macky-Sall_a87612.html (Accessed December 30, 2015).

Republic of Senegal (2006). Poverty Reduction Strategy Paper. Available online at: http://www.imf.org/external/pubs/ft/scr/2007/cr07316.pdf (Accessed February 1, 2015).

Republic of Senegal (2012a). NDESD 2013-2917 National Strategy for Economic and Social Development 2013-2017. Available online at: http://www.imf.org/ external/pubs/ft/scr/2013/cr13194.pdf (Accessed August 1, 2015).

Republic of Senegal (2012b). EPI Comprehensive Multiyear Plan 2012-2016. Ministry of Public Health and Prevention Department of Medical Prevention. Available online at: (Accessed February 5, 2015).

Rizzotto, A. C., and Demont, M. (2010). Extending Research to Strengthen Value Chains: Increasing Consumer Awareness of Quality Senegal River Valley Rice. Second Africa Rice Congress, Mali, 22-26 March 2010. Available online at: http://www.africarice.org/workshop/ARC/3.1\%20Rizzotto \%20fin.pdf (Accessed February 17, 2015).

Saarnak, N. L. (2003). Flood recession agriculture in the Senegal River Valley. Danish J. Geogr. 103, 99-113. doi: 10.1080/00167223.2003.10649483

SAED (2009a). Riz Irrigué. République du Sénégal. Ministère de l'Agriculture, 4. Available online at: (Accessed February 7, 2015).

SAED (2009b). Fiche Itinéraire Technique du Maïs. Ministère de l'Agriculture, 4. Available online at: (Accessed February 7, 2015).

SAED (2009c). L'oignon. Ministère de l'Agriculture. Société Nationale D’aménagement et D'exploitation des Terres du Delta du Fleuve Sénégal et des Vallées du Fleuve Sénégal et de la Falémé. Available online at: http:// agro-planet.e-monsite.com/medias/files/fiche-oignon.pdf (Accessed February $7,2015)$.

SAIC (2006). Life Cycle Assessment: Principle and Practice. National Risk Management Research Laboratory Office Research and Development US Environmental protection Agency, Cincinnati, OH. Available online at: http://nepis.epa.gov/Exe/ZyPDF.cgi/P1000L86.PDF?Dockey=P1000L86.PDF (Accessed August 20, 2015).

Salehe, F. S., and Hassan, S. N. (2012). Socio-economic effects of schistosomiasis on irrigation rice growers in Morogoro, Tanzania. Am. J. Exp. Agric. 2, 395-406. doi: 10.9734/AJEA/2012/1215

Sall, D. (2009). Étude sur L'évaluation des Cellules Nationales OMVS, Révue des Rôles, Responsabilités et Composition. Dakar: OMVS; PGIRE.

Salmone, F. A. (1998). Conflict in the Senegal River Valley. Culturl Survival Inc. Available online at: http://www.culturalsurvival.org/ourpublications/csq/ article/conflict-senegal-river-valley (Accessed June 17, 2015).

Samb, B., Dia, I., Konte, L., Ayala, D., Fontenille, D., and Couhet, A. (2012). Population Genetic structure of malaria vector Anopheles funestus, in a recently re-colonized area of the Senegal River basin and human-induced environmental changes. Parasit. Vectors 5:188. doi: 10.1186/1756-3305-5-188
Senghor, B., Diallo, A., Sylla, S. N., Doucouré, S., Ndiath, M. O., Gaayeb, L., et al. (2014). Prevalence and intensity of urinary schistosomiasis among school children in the district of Niakhar, region of Fatick, Senega. Parasit. Vectors 7:5. doi: 10.1186/1756-3305-7-5

Shah, T., van Koppen, B., Merrey, D., de Lange, M., and Samad, M. (2002). Institutional Alternatives in African Smallholder Irrigation: Lessons from International Experience with Irrigation Management Transfer. Research report no. 60. Colombo: International Water Management Institute. Available online at: http://www.iwmi.cgiar.org/Publications/ IWMI_Research_Reports/PDF/pub060/Report60.pdf (Accessed June 20, 2015)

Sid'Ahmed, B. O. (2013). Actualisation de L'étude D'impact Environnemental et Social (EIES) Rapport Final. OMVS, E4174v2, Dakar. Available online at: http://www.portail-omvs.org/sites/default/files/publications/files/pgire_2eies_pgire_ii_vf-diong.pdf (Accessed August 20, 2015).

Sow, S., de Vlas, S. J., Engels, D., and Gryseels, B. (2002). Water-related disease patterns before and after the construction of the Diama dam in northern Senegal. Ann. Trop. Med. Parasitol. 96, 575-586. doi: $10.1179 / 000349802125001636$

Talla, I., Kongs, A., Verlé, P., Belot, J., Sarr, S., and Coll, A. M. (1990). Outbreak of intestinal schistosomiasis in the Senegal River Basin. Ann. Soc. Belg. Méd. Trop. $70,173-180$

Tayaa, M., Saine, A., Ndiaye, G., and Deme, M. (2005). Global International Waters Assessment. Canary Current Regional Assessment 41. United Nations Environment Programme, 83.Available online at: http://www.unep.org/ dewa/giwa/areas/.../giwa_regional_assessment_41.pdf (Accessed February $8,2015)$

Tewe, O. O., Ojeniyi, F. E., and Abu, O. A. (1995). Sweet Potato Production, Utilization and Marketing in Nigeria. International Potato Center, Lima, Peru and University of Ibadan, Ibadan, Nigeria.

Touray, S., Bâ, H., Bâ, O., Koïta, M., Salem, C. B. O. A., Keïta, M., et al. (2012). Absence of dry season Plasmodium parasitaemia, but high rates of reported acute respiratory infection and diarrhoea in preschool-aged children in Kaédi, southern Mauritania. Parasit. Vectors 5:193. doi: 10.1186/1756-33055-193

UNDP (2011). Human Development Report 2011 - Sustainability and Equity: A Better Future For All. United Nations Development Programme. Available online at: http://hdr.undp.org/en/content/human-development-report-2011 (Accessed August 21, 2015).

UNEP (2009). Guidelines for Social Life Assessment of Projects. UNEP/SETAC Life Cycle Initiative at UNEP, CIRAIG, FAQDD and the Belgium Federal Public Planning Service Sustainable Development. Available online at: http://www. unep.org/pdf/DTIE_PDFS/DTIx1164xPA-guidelines_sLCA.pdf (Accessed August 23, 2015).

UNESCO (2003). A Joint Report by the Twenty-Three UN Agencies Concerned with Freshwater. Senegal River Basin, Guinea, Mali, Mauritania, Senegal, 450-461. Available online at: http://unesdoc.unesco.org/images/0012/001297/129726e. pdf (Accessed February 2, 2015).

USDA Foreign Agricultural Service (2015). Gain Report Global Agricultural Information Network. Available online at: http://gain.fas.usda.gov/Recent \%20GAIN\%20Publications/Grain\%20and\%20Feed\%20Annual_Dakar_ Senegal_4-29-2015.pdf (Accessed October 12, 2015).

van der Werf, M. J., Mbaye, A., Sow, S., Dryseels, B., and Vlas, S. J. (2002). Evaluation of staff performance and material resources for integtrated schistosomiasis control in Northern Senegal. Trop. Med. Int. Health 7, 70-79. doi: 10.1046/j.1365-3156.2002.00823.x

Vick, M. J. (2006). The Senegal River Basin: a retrospective and prospective look at the Legal Régime. Nat. Resour. J. 46, 211-243.

WHO (2004). Global Strategic Framework for Integrated Vector Management. Geneva: World Health Organization. Available online at: http://apps.who.int/ iris/bitstream/10665/68624/1/WHO_CDS_CPE_PVC_2004_10.pdf (Accessed August 28, 2015).

WHO (2008). WHO Guide for Standardization of Economic Evaluations of Immunization Programmes. Geneva: WHO Press.

WHO, c. (2014). Disability Weights, Discounting and Age Weighting DALY's. Available online at: http://www.who.int/healthinfo/global_burden_disease/ daly_disability_weight/en/ (Accessed April 19, 2015). 
WHO (2015). Media Centre Schistosomiasis (N0115) [Fact sheet]. Updated May 2015. Available online at: http://www.who.int/mediacentre/factsheets/fs115/ en/ (June 13, 2015).

World Bank (2013). Senegal River Basin Multi-Purpose Water Resources Development Project 2 Project Appraisal Document. Available online at: http://www-wds.worldbank.org/external/default/WDSContentServer/ WDSP/IB/2013/11/18/000461832_20131118132333/Rendered/PDF/ 767650PAD0GEF00R2013002830100OUO090.pdf (Accessed June 19, 2015).

World Bank (2014). How a Water Project is helping Fight Malaria in the Senegal River Basin. Available online at: http://www.worldbank.org/en/news/feature/ 2014/04/24/how-a-water-project-is-helping-fight- malaria-in-the-senegalriver-basin (Accessed July 11, 2015).

World Bank (2015). World Development Indicators. Available online at: http://data. worldbank.org/indicator (Accessed April 19, 2015).

World Bank (2006). Mali, Mauritania, Senegal and Guinea - Senegal River Basin Multi-Purpose Water Resources Development (APL) Project
Appraisal Document. Available online at: http://www-wds.worldbank.org/ external/default/WDSContentServer/WDSP/IB/2006/05/22/000160016 20060522122125/Rendered/PDF/34945.pdf (Accessed April 21, 2015)

Wright, W. H. (1972). A consideration of the economic impact of schistosomiasis. Bull. World Health Organ. 47, 559-565.

Conflict of Interest Statement: The authors declare that the research was conducted in the absence of any commercial or financial relationships that could be construed as a potential conflict of interest.

Copyright () 2016 Manikowski and Strapasson. This is an open-access article distributed under the terms of the Creative Commons Attribution License (CC BY). The use, distribution or reproduction in other forums is permitted, provided the original author(s) or licensor are credited and that the original publication in this journal is cited, in accordance with accepted academic practice. No use, distribution or reproduction is permitted which does not comply with these terms. 